\title{
LABRUS BIFASCIATUS.
}

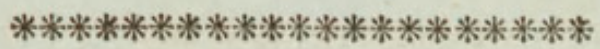

CHARACTER GENERICUS.

Dentes robusti subacuti: molares, interdum, conferti, convexi: labia crassa, duplicata : pinna dorsalis radii, in certis speciebus, ramento elongati.

Opercula mutica, squamosa.

CHARACTER SPECIFICUS, Ec.

LABRUS glaucus, capite rufo, corpore antice fasciis duabus transversis fuscis, cauda fusco arcuata.

LABRUS BIFASCIATUS. L. fasciis duabus brunneis.

Bloch ichth. t. 283.

Maria incolit Indica Labrus bifasciatus, magnitudine, ut plurimum, pedali. 




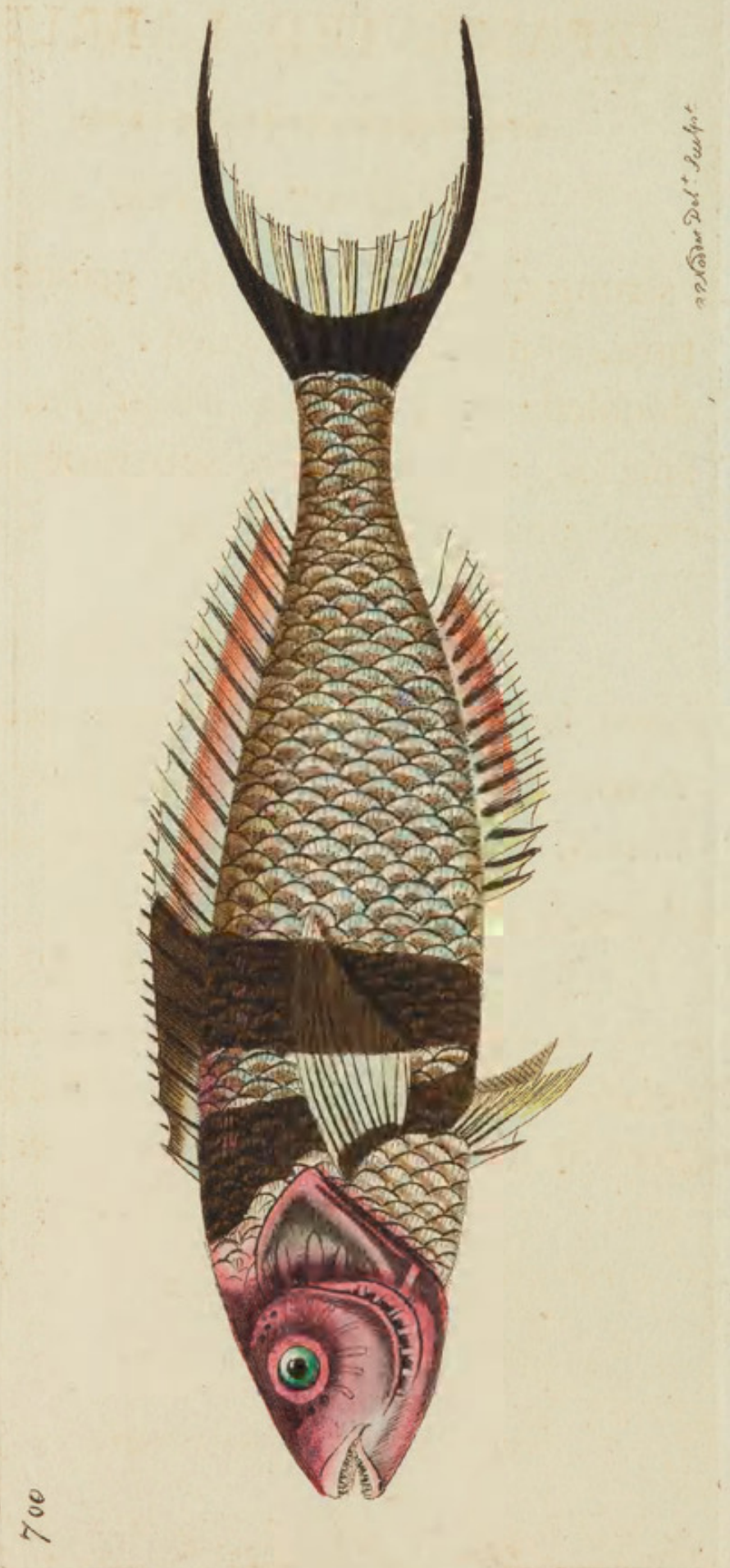




\section{THE \\ BIFASCIATED LABRUS.}

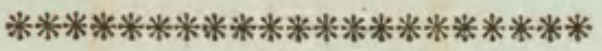

\section{GENERIC CHARACTER.}

Tecth strong and subacute: the grinders sometimes convex and crowded: lips thick and doubled: rays of the dorsal $f m$, in some species, elongated into soft processes.

Gill-covers unarmed and scaly.

$$
\text { SPECIFIC CHARACTER, Eं. }
$$

Glaucous LABRUS, with rufous head, body marked in front by two transverse brown. bands, and tail by a brown crescent.

Das doppelband.

Bloch ichth. pl. 283.

The bifasciated Labrus is a native of the Indian seas, and generally measures about twelve inches in length. 


\section{$2 \mathrm{BHL}$ Biodiversity Heritage Library}

Shaw, George. 1806. "The Bifasciated Labrus, Labrus bifasciatus [PI. 700]." The Naturalist's Miscellany 17(CCI), https://doi.org/10.5962/p.311137.

View This Item Online: https://www.biodiversitylibrary.org/item/281954

DOI: https://doi.org/10.5962/p.311137

Permalink: https://www.biodiversitylibrary.org/partpdf/311137

\section{Holding Institution}

Museums Victoria

\section{Sponsored by}

Atlas of Living Australia

\section{Copyright \& Reuse}

Copyright Status: Public domain. The BHL considers that this work is no longer under copyright protection.

This document was created from content at the Biodiversity Heritage Library, the world's largest open access digital library for biodiversity literature and archives. Visit BHL at https://www.biodiversitylibrary.org. 